\title{
経験的グリーン関数法を用いた2000年鳥取県西部地震の 震源のモデル化と強震動シミュレーション \\ SOURCE CHARACTERIZATION AND STRONG GROUND MOTION SIMULATION OF THE 2000 TOTTORI-KEN SEIBU EARTHQUAKE USING THE EMPIRICAL GREEN'S FUNCTION METHOD
}

\author{
池田隆明*, 釜 江 克宏**，三輪 滋***，入倉 孝次郎**** \\ Takaaki IKEDA, Katsuhiro KAMAE, Shigeru MIWA \\ and Kojiro IRIKURA
}

\begin{abstract}
In the 2000 Tottori-ken Seibu earthquake, many strong ground motions of the main-shock and the aftershocks have been observed at a lot of stations including near-source area. In this study, we attempted to construct a source model for broad-band strong ground motions by the forward modeling using the empirical Green's function method. We derived the best source model that consists of two asperities and background after several trials referring to the inverted source model by Sekiguchi and Iwata (2001). Two asperities are located in shallow and deep parts at the southeastern side of the hypocenter. We found that strong ground motions at near-source area were controlled by the areas and stress drops of two asperities. Relation between combined area of asperities and seismic moment of the best source model is in close agreement with the empirical relation by Somerville et al. (1999).
\end{abstract}

Keywords: 2000 Tottori-Ken Seibu earthquake, The best source model, Empirical Green's function method, Strong ground motion, Asperity, Source rupture process 2000 年鳥取県西部地震、最適震源モデル，経験的グリーン関数法，強震動，アスペリティ，震源破壊過程

\section{1.はじめに}

2000 年 10 月 6 日に鳥取県西部を震源とする $M_{M M 4}=7.3$ の地震が発 生した。この地震では，鳥取県の境港市と日野町で震度 6 強を観測 し '), 1995 年の兵庫県南部地震以降では, 国内で最も規模の大きい 地震であった。兵庫県南部地震に比べ, 震度の割には甚大な被害を 被った木造家屋は少なかった 2).37ものの, 山間部には多くの崖崩れや 地滑りを生じさせ，道路や鉄道の寸断といった被害が発生した。ま た, 臨海部では埋立地や干拓地で液状化が発生し, 港湾施設や農作 物へ大きな被害を与えた。このような大地震において，震源近傍を 含む広い範囲での地震動を広い周期帯にわたり適切に予測すること ができれば，防災対策および災害軽減に大きな効果があると考えら れる。

特定の活断層による地震を想定して地震動を予測する方法は数多 く提案されている. 最近は, 理論的方法と半経験的方法を組み合わ せたハイブリッド法 ${ }^{4.5}$ ににより三次元的な地盤構造に起因する堆積層 表面波などの影響も考慮できるようになってきた，深部地盤構造に ついての調查は近年精力的に行われてきており ${ }^{6)}$, 地盤のデータが蓄 積するにつれて全国的に展開可能な有用な方法になると考えられる. また，想定する断層付近の小地震の記録が予測するサイトで得られ ている場合は、経験的グリーン関数法 ${ }^{7) .8}$ が最も有効な方法である.
以前は地震観測記録が少なく，経験的グリーン関数として適切な地 震動記録を設定しにくいという課題があったが，兵庫県南部地震を 契機として，全国で強震動観測が多くの機関において積極的に展開 されてきており ${ }^{9}$, この課題も解決されつつある.

高精度な強震動予測を実現するための最重要課題は震源のモデル 化であり，特に断層面上でのすべりの不均質性を考慮した震源のモ デル化手法に関する研究が精力的に進められている ${ }^{10),(1), 12),(3) .}$

釜江・入倉 ${ }^{14}$ は，1995 年兵庫県南部地震に対して，波形インバー ジョン結果を参考に断層面上のすべり量の大きいところにアスペリ ティを設定し，経験的グリーン関数法を用いたフォワードモデリン グによってアスペリティの大きさ，地震モーメント，応力降下量な どのパラメータを定量化した（アスペリティモデル）．結果として長 周期地震動記録を使った波形インバージョン解析から求めたアスペ リティモデルが短周期領域も含んだ広帯域強震動予測に有効である ことを示した. 同様な手法が 1994 年ノースリッジ地震, 1999 年トル コ・コジャエリ地震, 1999 年台湾・集集地震など ${ }^{(5), 16), 17}$ にも適用さ れ，アスペリティモデルが検証されている.

一方, 統計的に断層面上でのすべりの不均質性を抽出する試みが

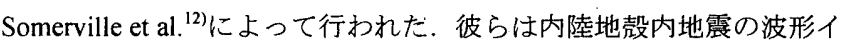
ンバージョン結果からアスペリティ（断層面上のすべりの相対的に
* 飛島建設(侏技術研究所 区修

** 京都大学原子炉実験所 助教授 · 工博

*** 飛島建設侏技術研究所

**** 京都大学防災研究所 教授・理博
Technical Research Institute, Tobishima Corp., M. Eng.

Assoc. Prof., Research Reactor Institute, Kyoto Univ., Dr. Eng.

Technical Research Institute, Tobishima Corp.

Prof., Disaster Prevention Research Institute, Kyoto Univ., Dr. Sci. 
大きい領域）を抽出し，その結果破壊域の面積やアスペリティの面

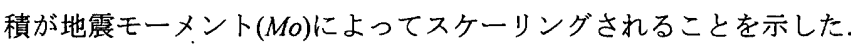
その後, Miyakoshi et al. ${ }^{18}$ は同様な方法により日本国内で発生した中 規模地震において検討を行い，このスケーリング則が成り立つこと を示している.さらに宮腰 ${ }^{19}$ は, 1999 年に相次いで発生したトルコ・ コジャエリ地震と台湾・集集地震についても検討を行い, Somerville et al.が統計解析に用いたMoよりも大きいMoに対してもこのスケー リング則が成り立つことを示している.この結果は前述のフォワー ドモデリングでの検証事例を背景として, 既に将来の内陸地款内地 震や海溝型巨大地震の広帯域強震動予測のための特性化震源モデル に適用されている ${ }^{20)}$.

本研究ではアスペリティモデルの有効性はより多くの地震によっ て検証すべきとの観点から，2000 年鳥取県西部地震を対象に釜江・ 入倉と同様の手法を用いて広帯域強震動評価のための最適震源モデ ルを構築した，鳥取県西部地震では，震源ごく近傍を含めた多くの 地点における本震および余震での地震動記録が，防災科学技術研究 所が実施している強震観測網(K-Net) ${ }^{21)}$, 基盤強震観測網(KiK-Net $)^{22)}$, 高感度地震観測網(Hi-Net) $)^{23}$ において得られ web を通じて公開されて いる．また，地震直後にこれらの記録を用いた波形インバージョン 解析による複雑なすべり量分布が報告されており 24).25).26.27).28)，経験 的グリーン関数法によるフォワードモデリングの適用条件が揃って いる.

\section{2. 鳥取県西部地震の震源破壊過程}

前述のように鳥取県西部地震では, 地震発生直後に関口・岩田 ${ }^{24), 25)}$ 堀川 ${ }^{26)}$, 井出 ${ }^{27)}$, Yagi and Kikuchi ${ }^{28)}$ により震源の破壊過程が報告さ れている.いずれも，震源周辺の K-Net，KiK-Net 等により得られた 地震動記録を用いた波形インバージョン解析により得られたもので あり，複雑な震源の破壊過程が示されている。これらの結果を比較 すると，相互に異なる点が見られる。これは，波形インバージョン 解析に用いたデータ，解析方法による差であると考えられる.

その後, 関口・岩田モデル(以後, 関口・岩田[2000]モデルと称す) は，(1)断層面を福山ら ${ }^{299}$ の高精度余震分布を参考に 5 枚のセグメン トからなるモデルに変更し，(2)震源を Hi-Net の震源情報に基づき浅 くし ${ }^{30)}$ ，(3)断層面上の浅い部分の拘束が十分ではなかった点を，す ベりに感度の強い国土地理院による GPS および水準測量による地殼 変動データおよび最浅のサブフォールトのすべりを抑える拘束を加 える, などの検討を加えることによって再評価されている ${ }^{31)}$ (以後, 関口・岩田[2001]モデルと称す).

関口・岩田[2001]モデルを図 1 に示す.すべり量の大きな領域の大 部分は震源の南東側に見られ，かなり浅い部分にまでも広がってい る.これに対して, 震源付近のすべり量は小さいことがわかる. 今 回の震源付近では 1989 年, 1990 年, 1997 年に群発的地震活動(Mj=5.1 〜 5.4)が発生しており，涉谷ら ${ }^{32}$ は余震の震央分布から今回の地震を 含めた 4 回の地震は全て同じ地震断層の一部が活動したものとして いる．また，以前の活動では断層運動の進展を妨げるバリアのよう なものが存在し大地震に成長しなかったが，今回の地震では震源に 対して比較的浅い部分が活動したため, 断層運動が一気に進展し $\mathrm{Mj}$ が 7 を超えるような大地震へと成長したとしている。これらの知見 は, 関口・岩田[2001]モデルのすべり分布と調和しており, 関口・岩
田[2001]モデルの信頼性は高いと考えられる.

また，今回の地震では明瞭な初期破壊が観測されている．梅田ら ${ }^{33)}$ によれば，初期破壊は震源から出発し南東方向のやや深い方向に $7 \mathrm{~km}$ すすみ，そこで第二の破壊(主破壊)が始まったとしている，さら に，平田ら ${ }^{34)}$ は，初期破壊と主破壊の震源の再決定を行っており， 主破壊開始点は震源の南東のすべり量が大きい領域の下部に位置し ているとしている ${ }^{35)}$. その梁さは，初期破壊開始点が約 $7 \mathrm{~km}$ である のに対して，主破壊開始点は 7.5〜 11km の範囲にばらつくとしてい $3^{36)}$. 図 1 に文献 35)に示された初期破壊開始点( $\nabla$ 印) と主破壊開始 点( $\triangle \mathrm{F})$ を示す．また主破壊開始点のばらつきの範囲を矢印で示す.

関ロ・岩田はインバージョン結果より，震源で始まった破壊はい ったん主破壊開始点付近に移動し，そこから上向きおよび北西上向 きに進む，つまり回り込んでいるような現象があるとしている．従 って, 震源から破壊が同心円状に伝播すると考えた場合と異なる破 買伝播を示す.

このように鳥取県西部地震の震源の破壊過程は複雑であるため, 震源モデルの設定においてもこの破壊過程を参考とした.

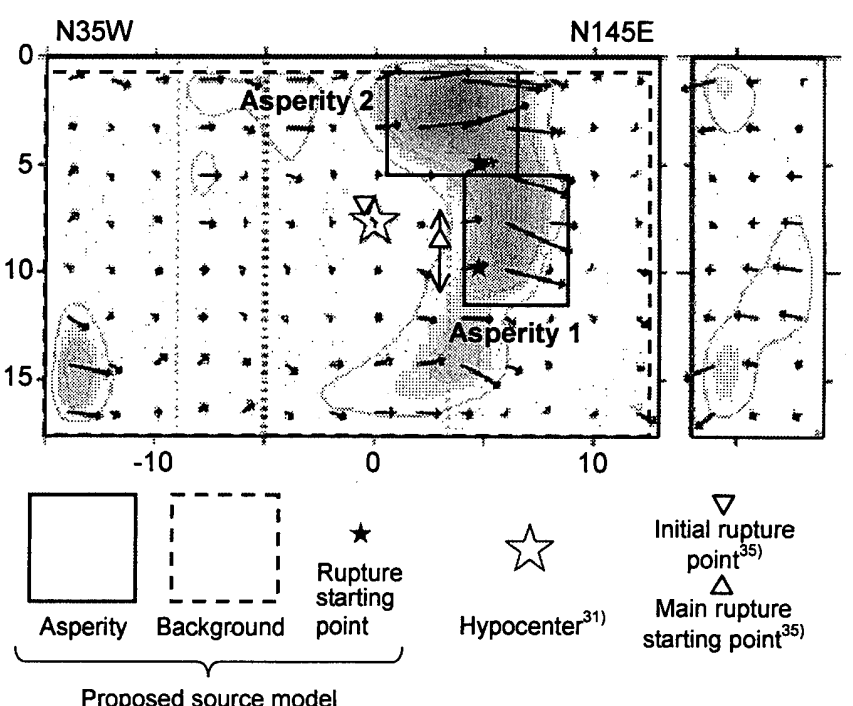

図 1 提案する鳥取県西部地震の最適震源モデル (関口・岩田 ${ }^{31}$ に加筆・修正)

\section{3. 経験的グリーン関数として用いる余震記録}

鳥取県西部地震では，多くの余震記録が観測されており，K-Net および Kik-Net で観測された記録は web を通じて公開されている. 本検討では公開された余震記録の中から，規模が比較的大きく，震 源メカニズムが本震と類似しており，多くの観測地点で記録が得ら れている等の観点から，10月 17 日 22 時 16 分の $\mathrm{M}_{M L 4}=4.2$ の余震に よる記録を経験的グリーン関数として使用する，この余震では，半 径約 70km 以内では K-Net が 21 観測地点, Kik-Net が 15 観測地点で の記録が得られており, 震源周辺の地震動を評価するには十分な点 数と考えられる. なお， Kik-Net は全て地中の観測点を対象とする.

表 1 に余震の諸元を, 図 2 には本震および余震の震央と, 強震動 シミュレーションの対象地点を示す. また, 右上には本震と余震の 震源メカニズムを示す．本震と余震の震源メカニズムは類似してい ることがわかる．地震モーメントとメカニズム解は広帯域地震観測 網(FREESIA) ${ }^{37}$ による結果である. 
応力降下量および面積は，コーナー振動数 $(f c)$ を震源ごく近傍の Kik-Net の観測地点である日野(TTRH02)および伯太(SMNH02)の地中 の観測波形から求めた震源変位スペクトルから $f_{c}=2.0 \mathrm{~Hz}$ と読みとり, Brune の式 ${ }^{38) .39}$ により評価した. 図 3 にTTRH02における震源変位 スペクトルを示す. 震源変位スペクトルの算定においては，幾何減 衰と媒質の $\mathrm{Q}$ 值 $(\mathrm{Q}=150 \mathrm{f})^{(0)}$ による減衰の補正を実施した. 低振動数側 のズペクトル一定值から平均的なラディエーションパターン係数を 用いて $M o$ を求めると $2.2 \times 10^{15} \mathrm{Nm}$ となり,FREESIA による $M o$ と同 程度である.

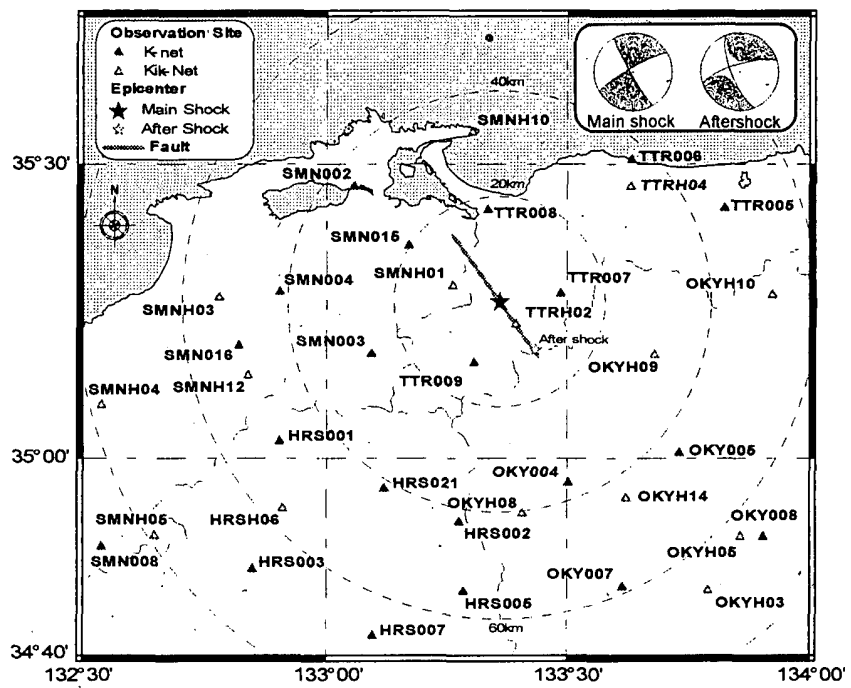

图 2 本震および余震の震央位置と強震動シミュレーション の対象地点，および余震の位置とメカニズム解

表 1 余震の諸元

\begin{tabular}{ccc}
\hline 発生日時 $^{23)}$ & $2000 / 10 / 1722: 16$ \\
\hline $\mathrm{M}_{M\left(44^{41)}\right.}$ & & 4.2 \\
\hline 震源位置 $^{23)}$ & & $35.182 \mathrm{~N}, 133.434 \mathrm{E}$ \\
\hline Strike, Dip , Slip ${ }^{37)}$ & deg. & $309,87,18$ \\
\hline 震源深さ $^{23)}$ & $\mathrm{km}$ & 4.7 \\
\hline 面積 $^{37)}$ & $\mathrm{km}^{2}$ & 1.44 \\
\hline 地震モーメント & $\mathrm{Nm}$ & $2.84 \times 10^{15}$ \\
\hline 応力降下量 & $\mathrm{MPa}$ & 4.0 \\
\hline
\end{tabular}

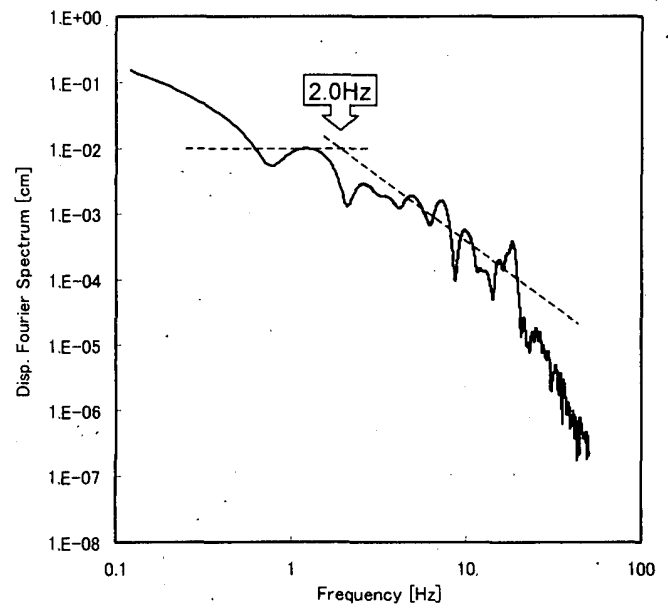

図 3 Kik-Net 日野(TTRH02)の地中観測記録から求めた 震源変位スペクトル

\section{4. 震源のモデル化}

2 章で示したように，関ロ・岩田[2001]モデルは最新の情報を用い てモデルの修正が行われており、その結果は過去の地震活動も含め た余震分布から今回の地震の破壊過程を推定した涉谷ら ${ }^{32)}$ の知見と も調和的であり，信頼性が高いと考えられる，そこで，このモデル を初期モデルとして, フォワードモデリングにより最適震源モデル を構筑する．震源モデルの設定手順は以下の通りである．(1)これま でに発生した大地震における震源モデルの検討結果から ${ }^{14) .15) .16)}$ ，す べり量の大きいところから短周期から長周期までの強震動が生成さ れるとし，そこにアスペリティを設定する. (2)アスペリティの位置 や大きさを，観測波形に見られる特徽的な波形（フォワードディレ クティビティ効果によるパルスなど）に着目し，その周期や振幅が 一致するように調整する。.この際の観測波形は，アスペリティから の強震動が支配的と考えられる震源近傍の観測地点での波形とする: (3)合成波形の振幅はアスペリティの忘力降下量や $f_{\max }$ の補正で調整 する. (4)破壊伝播は関口・岩田のインバージョン結果を参考とする. (5)アスペリティ以外の背景領域もモデル化する.

図 1 に設定した最適震源モデルを, 表 2 には Kik-Net の観測地点の うち, 震源近傍の SMNH01，TTRH02，北房(OKYH14)の 3 地点での 地中観測波形との一致度から得られた最適震源モデルの震源パラメ 一タを示す.アスペリティはすべり量の大きい震源の南東側の浅い 部分と深い部分の二箇所に設定された．本論文では，深い方を Asperityl，浅い方を Asperity2 と呼ぶこととする．破壊領域からアス ペリティを除いた部分が背景領域である.

関口・岩田[2001]モデルは前述のように5つの断層セグメントを想 定しているが，南西〜北西にのびるブランチ部分の断層面を無視し， 走向 N145E，傾斜角 90 度のひとつの断層面としてモデル化した. 断 層面の地表トレースを図 2 に示す。

表 2 最適震源モデルのパラメータ

\begin{tabular}{|c|c|c|c|c|}
\hline 震源位置 ${ }^{\text {+3) }}$ & & \multicolumn{3}{|c|}{$35.26937 \mathrm{~N}, 133.35669 \mathrm{E}$} \\
\hline \multicolumn{2}{|c|}{ Strike, Dip, Slip } & deg. & \multicolumn{2}{|c|}{$145,90,0$} \\
\hline \multicolumn{2}{|l|}{ 震源深さ +3) } & $\mathrm{km}$ & \multicolumn{2}{|l|}{7.8} \\
\hline \multicolumn{2}{|c|}{ 地震モーメント ${ }^{45)}$} & $\mathrm{Nm}$ & \multicolumn{2}{|c|}{$9.6 \times 10^{18}$} \\
\hline \multicolumn{2}{|l|}{ 破壊域の面積 } & $\mathrm{km}^{2}$ & \multicolumn{2}{|l|}{464} \\
\hline \multicolumn{2}{|l|}{ せん断波速度 } & $\mathrm{km} / \mathrm{s}$ & \multicolumn{2}{|l|}{3.5} \\
\hline & & \multicolumn{2}{|c|}{ アスペリティ } & \multirow{2}{*}{ 背景領域 } \\
\hline & & 1 (下部) & 2 (上部) & \\
\hline 面積 & $\mathrm{km}^{2}$ & $\begin{array}{c}28.8 \\
(4.8 \mathrm{~km} \times 6.0 \mathrm{~km})\end{array}$ & $\begin{array}{c}28.8 \\
(6.0 \mathrm{~km} \times 4.8 \mathrm{~km})\end{array}$ & 410.4 \\
\hline $\begin{array}{l}\text { 重ね合わせ数 } \\
\left(N_{\mathrm{L}} \times N_{\mathrm{W}} \times N_{\mathrm{T}}\right) \\
\end{array}$ & & $4 \times 5 \times 5$ & $5 \times 4 \times 5$ & $\begin{array}{r}282 \times 17 \\
\| \\
N_{\mathrm{L}} \times N_{\mathrm{W}} \\
N_{\mathrm{T}} \\
\end{array}$ \\
\hline 上端深さ & $\mathrm{km}$ & 5.6 & 0.8 & 0.8 \\
\hline 地震モーメント & $\mathrm{Nm}$ & $1.99 \times 10^{18}$ & $0.99 \times 10^{18}$ & $6.62 \times 10^{18}$ \\
\hline 忘力降下量 & $\mathrm{MPa}$ & .28 .0 & 14.0 & 2.8 \\
\hline 破壊伝播速度 & $\mathrm{km} / \mathrm{s}$ & 2.5 & 3.0 & 2.5 \\
\hline ライズタイム & s & 0.6 & 0.6 & 2.04 \\
\hline
\end{tabular}




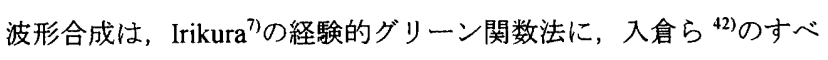
り速度関数の補正式を適用した方法で実施した。

破壊開始地点は, 主破壊開始点を参考に, 図 1 中に示す Asperity1 内の 印から円状に広がるとし, 破壊が Asperity2 内のれ印に到達し た後, 再び円状に伝播すると仮定した. 従って, Asperity2 内での破 壊伝播様式は関口・岩田[2001]モデルと整合する. また, 破壊伝播速 度は関口・岩田[2001]モデルを参考に, Asperity1 内では $2.5 \mathrm{~km} / \mathrm{s}$, Asperity2 内では $3.0 \mathrm{~km} / \mathrm{s}$ と仮定した ${ }^{43}$.

Asperity1 の面積およびライズタイムは, フォワード側にあたる OKYH14 での地中速度波形に見られた周期約 1 秒程度のパルスを再 現できるように試行錯誤を行い設定した. ライズタイムは，0.4 秒か ら 1.0 秒まで 0.1 秒刻みで変化させ, 最も波形の一致度が高い值を設 定した。 その結果, 面積は $4.8 \mathrm{~km} \times 6.0 \mathrm{~km}\left(28.8 \mathrm{~km}^{2}\right)$, ライズタイムは 0.6 秒とした. なお，余震の面積 $\left(1.44 \mathrm{~km}^{2}\right)$ から断層の分割幅が $1.2 \mathrm{~km}$ となるため, アスペリティの大きさはこの值の倍数に拘束される. 同様に Asperity2 は SMNH01 の地中観測波形を対象に検討を行い, 面 積が $6.0 \mathrm{~km} \times 4.8 \mathrm{~km}\left(28.8 \mathrm{~km}^{2}\right)$, ライズタイムは 0.6 秒とした. また, 本震と余震の応力降下量の比は Asperityl が 7.0, Asperity2 が 3.5 と し,アスペリティの地震モーメントと応力降下量は次式から設定し た.

$$
\begin{aligned}
& \text { Moa }=\text { Moe } X_{C} \times N_{L} \times N_{W} \times N_{T} \\
& \Delta \sigma a=\Delta \sigma e X_{c} \\
& \text { ここで, Moa : アスペリティの地震モーメント } \\
& \text { Moe : 余震の地震モーメント } \\
& \text { c : : 応力降下量の比(アスペリティ/余震) } \\
& N_{L}, N_{W}, N_{T} \text { : 波形合成における重ね合わせ数 } \\
& \Delta \sigma a \text { : アスペリティの応力降下量 } \\
& \Delta \sigma e \text { : 余震の応力降下量 }
\end{aligned}
$$

なお，設定されたアスペリティのライズタイムは 1995 年兵庫県南 部地震の最適震源モデル ${ }^{14} に$ における值と同じである。

背景領域については, Asperityl 内のれ印から破壊が円状に広がる と仮定し，アスペリティと同様に $\omega^{-2}$ の波形が生成されると考えて波 形合成を行った. 宮武によるダイナミックモデルの計算では ${ }^{44)}$, ア スペリティと背景領域での最大すべり速度の大きさは異なるものの， すべり速度関数の形状は似たものとなっており，この仮定は近似的 に有効と考えられる、背景領域の面積は, 破壊域の面積を菊地・山 中 ${ }^{45)}$ の地震モーメントを Somerville et al. ${ }^{12)}$ の経験式に適用して求め, そこからアスペリティの面積を减じて設定した. 地震モーメントは, 全地震モーメントからアスペリティの地震モーメントを减じて設定 した. 応力降下量はアスペリティと同様に設定した. 破壊伝播速度 はAsperity1 と同じ $2.5 \mathrm{~km} / \mathrm{s}$ とし, ライズタイムは断層パラメータの スケーリング則に基づき ${ }^{46)}$, アスペリティのライズタイムから 2.04 秒と仮定した.

図 4(a)〜(c)に SMNH01, TTRH02, OKYH14の 3 地点における地 中観測速度波形と合成速度波形とを比較して示す. 図は上から観測 波形, アスペリティと背景領域をあわせた全体の合成波形, Asperity1 のみの合成波形, Asperity2 のみの合成波形, 背景領域のみの合成波 形, アスペリティのみ(Asperity1+Asperity2)の合成波形である.

余震記録はその精度を考慮して, SMNH01 と OKYH14 では $0.125 \mathrm{~Hz}$ $\sim 10.0 \mathrm{~Hz}$, TTRH 02 では $0.3 \mathrm{~Hz} \sim 10.0 \mathrm{~Hz}$ のバンドパスフィルター処理
を行った. 当初 $f_{\text {max }}$ を補正しない合成をしたところ, $5 \mathrm{~Hz}$ 付近以上の 振動数領域における合成結果が大きめの評価となったため, 本震と 余震の高周波遮断振動数 $\left(f_{\text {max }}\right)$ の補正を実施した。本震の $f_{\text {max }}$ を Faccioli ${ }^{47)}$ の経験式で評価すると $5.5 \mathrm{~Hz}$ となり，概ね整合したため, 本検討では $f_{\text {max }}$ をこの経験式から評価して補正した。 ただし，佐藤 ${ }^{48)}$ は鳥取県西部地震を対象に，Kik-Net での観測波形を用いて $f_{\max }$ に関 する検討を行っており， $f_{\text {max }}$ には明瞭な地震規模依存性は見られない という報告もある. 本震と余震の震源放射特性の違いは，それぞれ のセンスが異なる時のみ，補正係数を-1 とし，これを合成波形に乗 じて補正した.

いずれの地点においても，断層破壊の指向性効果によるパルス状 の波形が良く再現できている. 特に, 断層走向方向にあたる OKYH14 では主要動部の初期に見られる 1 秒程度のパルスが良く再現できて いる．最大值については多少ばらつきが見られ，TTRH02 では，上 下方向は観測波形と合成波形との一致度は高いが，水平方向の合成 波形は大きめの評価となっている，これは，兵庫県南部地震でのポ ートアイランドでの鉛直アレー観測波形などからわかるように，上 下動に比べ水平動の方が地盤の非線形の影響を受けやすいため ${ }^{49)}$ 考えられる.TTRH02 の地中観測点は花岡岩中に設置されているが, $\mathrm{Vs}$ は $790 \mathrm{~m} / \mathrm{s}$ と花骨岩としては小さく一様に風化が進んだ状態と考 えられること ${ }^{50), 51)}$, 地表付近の地盤は顕著な非線形性を示している ことから ${ }^{52)}$,ここでの観測波形は地盤の非線形性の影響を受けてい る可能性が高いと考えられる.

SMNH01 においては, NS 方向の一致度は波形，最大值ともに高い が，EW 方向および上下方向では最大值の一致度が低い.これは応力 降下量の設定だけでは説明できなく，今回は符号のみで補正した本 震と余震の震源放射特性の違いを補正することが重要であることを 示唆するものと考えられる.

図 4 からわかるように, 3 地点ともに全体の合成波形とアスペリテ イのみを考虑した合成波形には大きな差異は見られず，背景領域の 寄与は小さいことがわかる. 図 5 には 3 地点での観測波形とアスペ リティのみを考慮した合成波形の NS 成分の変位フーリエスペクト ルをそれぞれ比較して示す，一部の周波数帯域では小さめに評価し ているものの, 変位フーリエスペクトルは低周波から高周波までの 広い周波数領域において概ね一致していると考えられる.

今回の最適震源モデルは, すべり量の大きい領域にアスペリティ を設定し，短周期地震動も長周期地震動もそこから生成されると考 えて得られたものである. 一方, 松元・岩田 ${ }^{53}$ は経験的グリーン関 数法を用いたエンベロップインバージョンから，断層面上での高周 波地震動の生成過程の推定を行い, 高周波発生強度の高い領域は波 形インバージョンで得られたすべりの大きい領域の周囲に分布して いることを示している.これは, 高周波地震動はアスペリティ以外 の部分からも多く放出されるということを意味しており，エンベロ ップインバージョンの精度がまだ十分ではないものの, 震源モデル の構築にとっては重要な問題であり，今後の検討課題としたい.

本検討では, 破壊開始地点を梅田らの主破壊開始点を参考に震源 の南東に位置する Asperityl 内に設定し，かつ Asperity2 も南東から 北西に破壊伝播するように破壊開始点を設置することによって，関 ロ・岩田[2001]モデルと整合させている.これに対して, 通常考えら れるような震源から同心円状に破壊伝播するとした場合の合成波形 


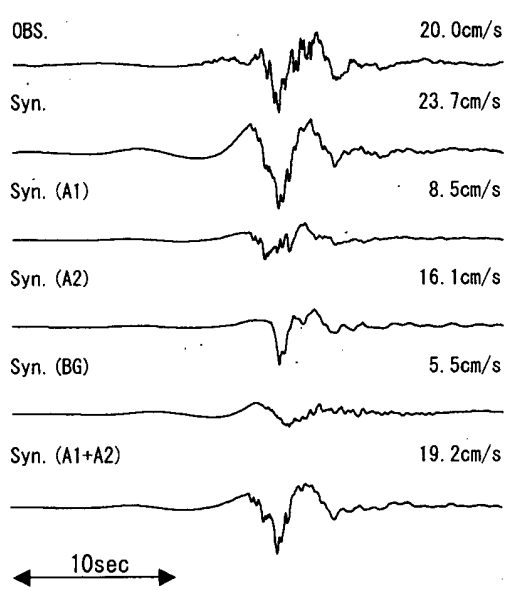

NS 成分

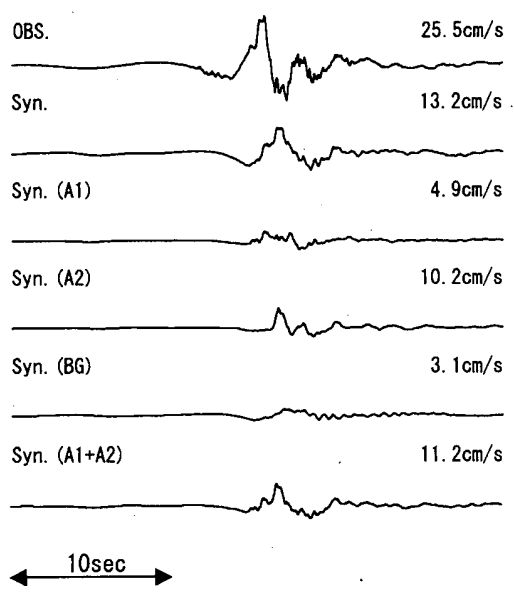

$\mathrm{EW}$ 成分

(a)SMNH01

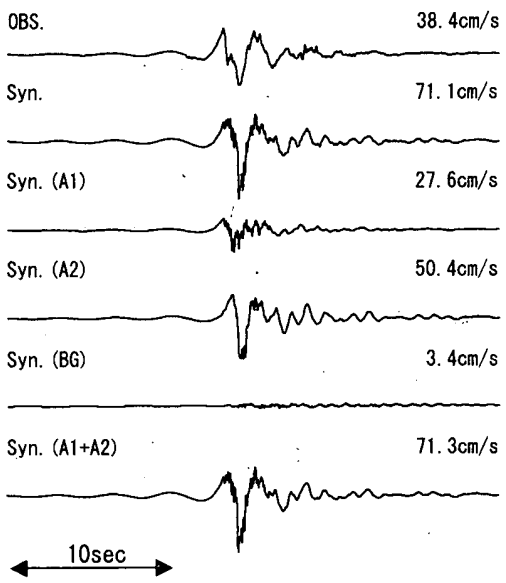

NS 成分

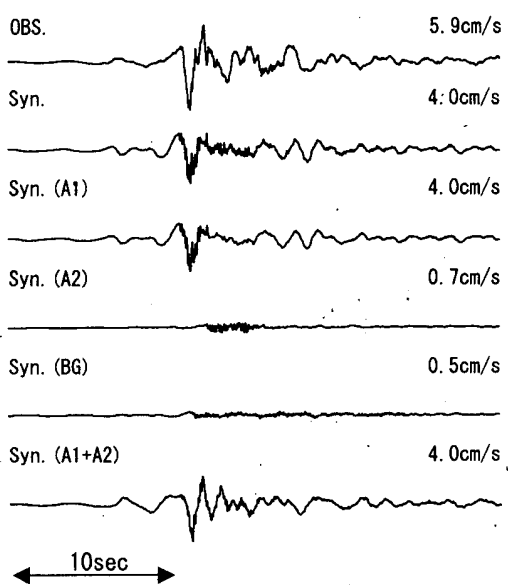

NS 成分

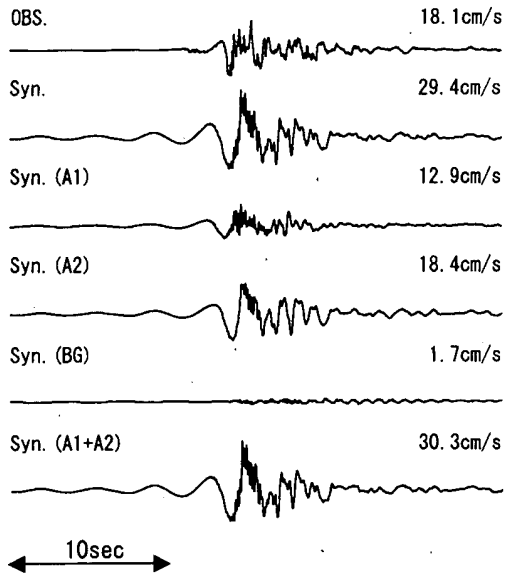

EW 成分

(b)TTRH02

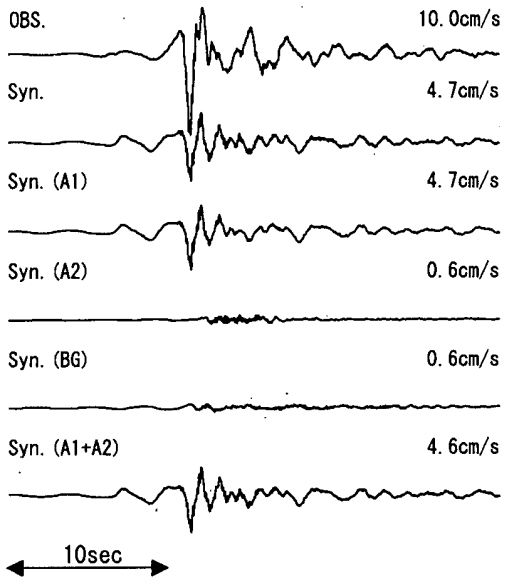

EW 成分

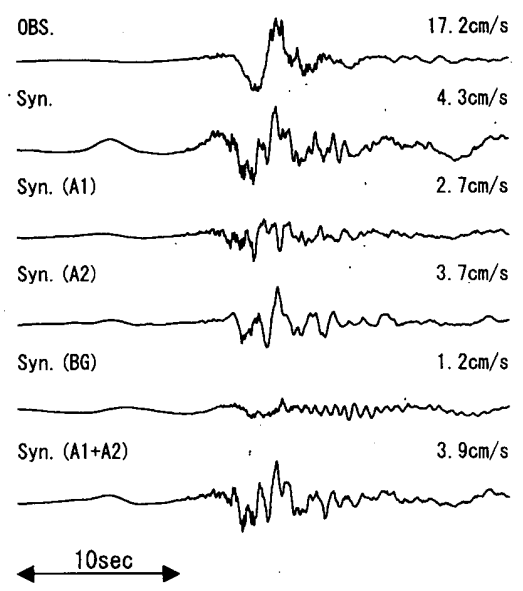

UD 成分

(OBS.は縮尺が 1/4)

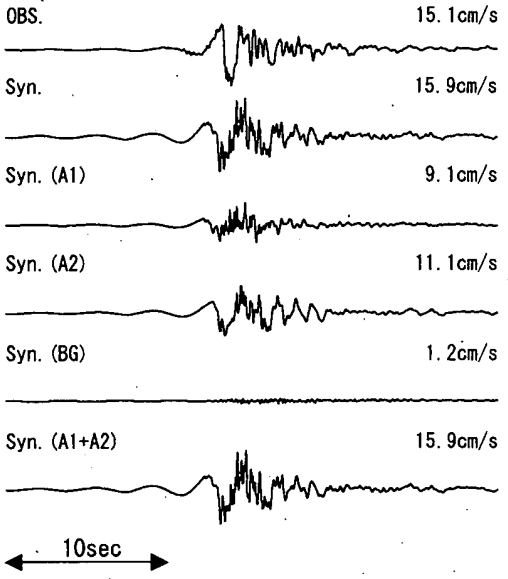

UD 成分

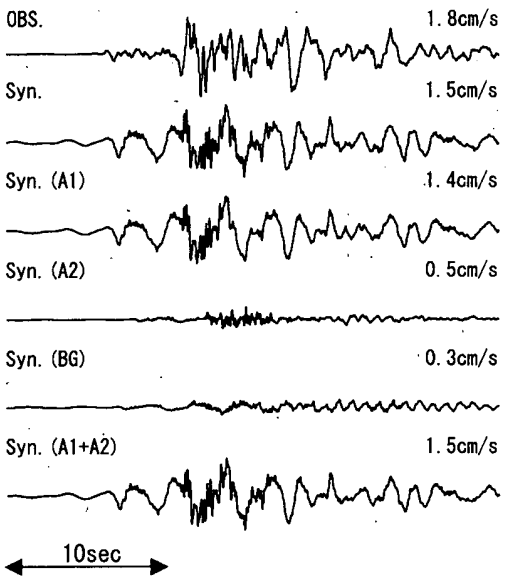

UD 成分

(c)OKYH14

図 4 伯太(SMNH01)，日野(TTRH02)，北房(OKYH14)における地中の観測速度波形と合成速度波形との比較 (各図とも上から，観測記録，合成結果，Asperity1のみ，Asperity2のみ，背景領域のみ，アスペリティのみの合成結果) 


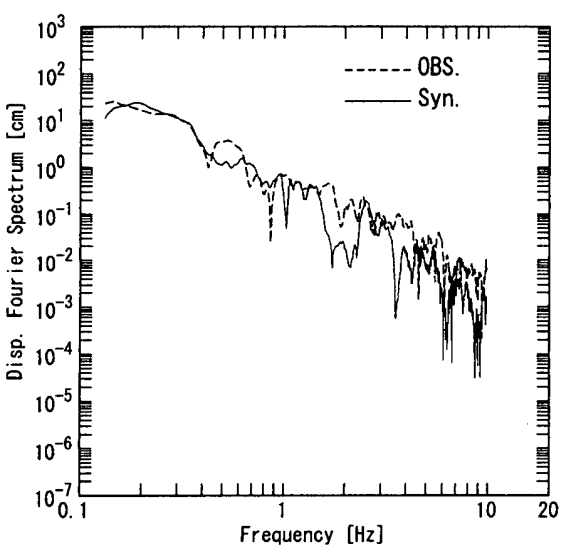

(a)SMNH01

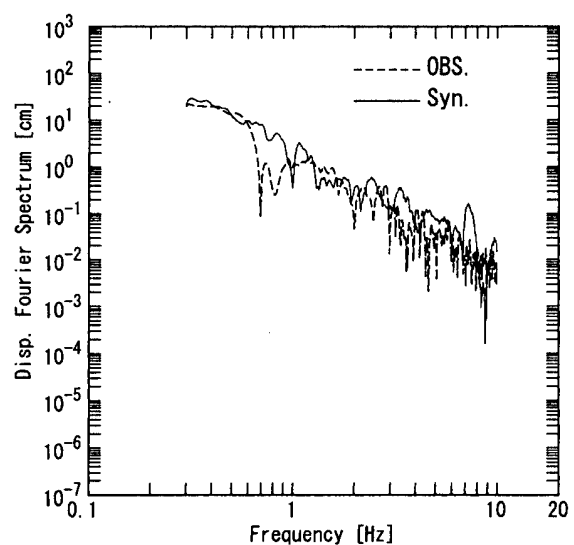

(b)TTRH02

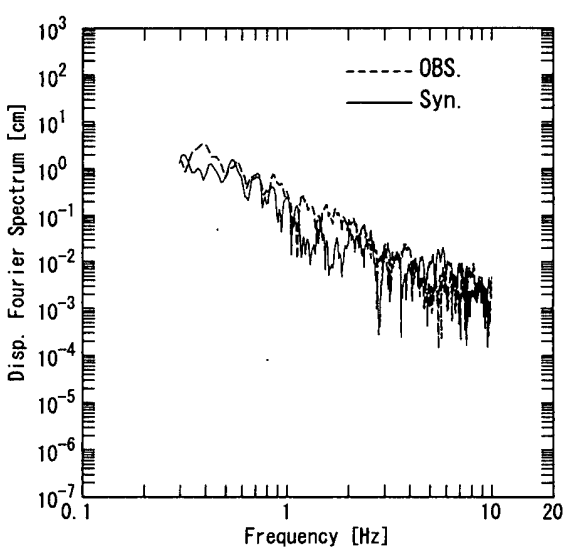

(c)OKYH14

図 5 伯太(SMNH01)，日野(TTRH02)，北房(OKYH14)における地中の観測波形とアスペリティのみを考慮した合成波形との 変位フーリエスペクトルの比較(NS 成分)

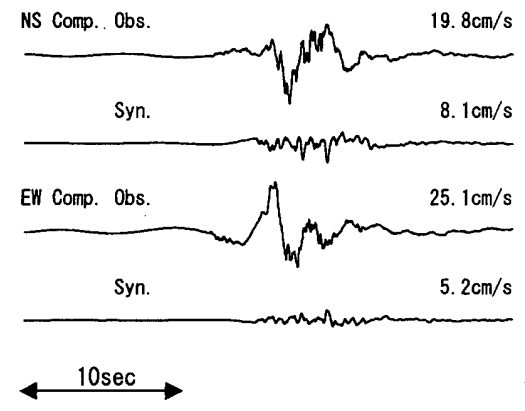

(a)SMNH01

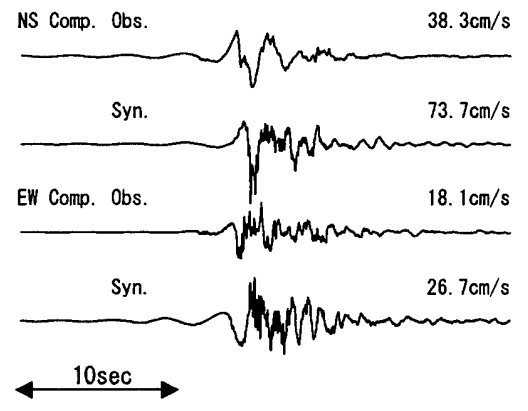

(b)TTRH02

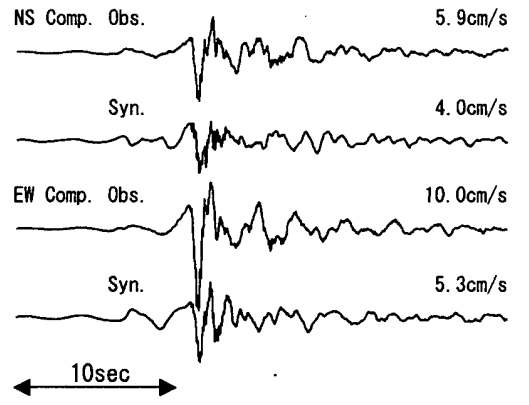

(c)OKYH14

図 6 地中の観測速度波形と震源から同心円状に破壊伝播するとした場合の合成速度波形（アスペリティのみを考慮）の比較

を図 6 に示す.フォワードとなる TTRH02 および OKYH14 では同程 度の結果が得られるが, バックワードとなる SMNH01 にはパルス状 の波形は再現できない，このことは，鳥取県西部地震の震源モデル では，破壊伝播様式が複雑なため，これを適切に評価することが重 要であることを示していると考えられる.

図 7 に前述した Somerville et al. ${ }^{12)}$, Miyakoshi et al. ${ }^{18)}$, 宮腰 ${ }^{19}$ が示 したアスペリティの総面積と地震モーメントとの関係に本検討結果

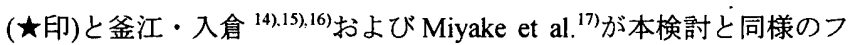
オワードモデリングにより国内外の大〜中規模の地震に対して求め

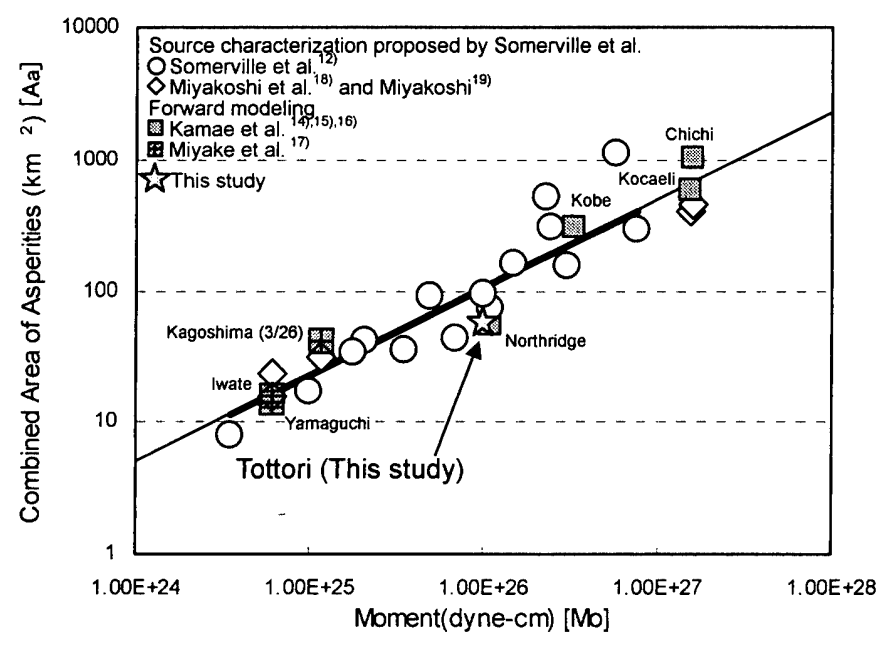

図 7 アスペリティの総面積と地震モーメントとの関倸
た結果をあわせて示す.図中の実線は Somerville et al.が提案したアス ペリティの総面積と地震モーメントとのスケーリング則であり，太 線部分は Somerville et al.が検討に用いた Mo の範囲を示す. 本検討結 果はアスペリティの総面積は小さめであるものの, Somerville et al. によるアスペリティの総面積と地震モーメントの関係式でほほ表現 できると考えられる.

\section{5. 震源周辺地点の強震動シミュレーション}

設定した最適震源モデルを用い，図 1 に示す観測地点のうち， TTRH02, SMNH01, OKYH14 を除く震源周辺地点を対象に経験的グ リーン関数法を用いた強震動シミュレーションを実施した. Kik-Net は地中観測地点を対象とした. 図 8 に Kik-Net の観測地点のうち, 震 源から少し離れた赤碕(TTRH04), 岡山(OKYH03), 口和(HRSH06)の 3 地点に扔ける $\mathrm{EW}$ 成分の加速度と速度について, 観測波形と合成波 形とを比較して示す，余震記録にはそれぞれの波形の精度に基づき バンドパスフィルター(TTRH04: $0.125 \mathrm{~Hz} \sim 10.0 \mathrm{~Hz}, \mathrm{OKYH} 03$, HRSH06 :0.4Hz〜10.0Hz)を作用させている.

各地点とも合成加速度波形の継続時間や包絡形状は観測波形と良 く一致している．合成速度波形についても，長周期波形の位相や形 状はよく再現できている。 OKYH03 の観測波形には，OKYH14より も振幅は小さいが，フォワードディレクティビティ効果による同様 のパルス状の波形が見られるが，これについてもよく再現できてい る.

最大加速度の再現精度は $f_{\max }$ の補正により高くなっているものの， 


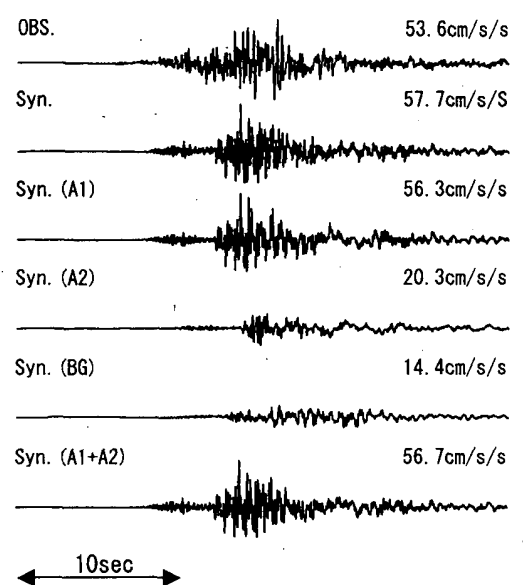

TTRH04

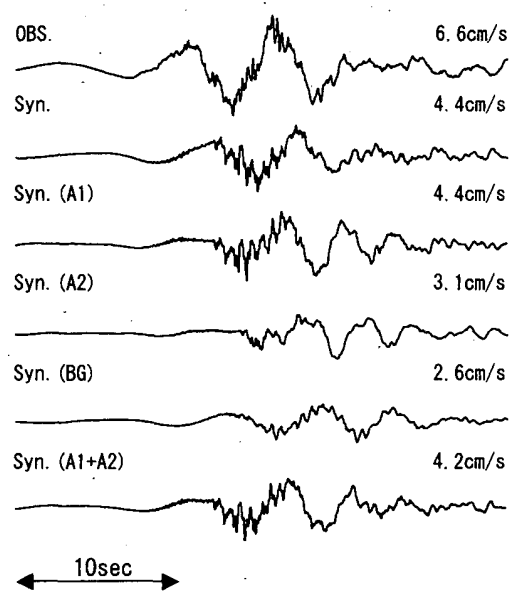

TTRH04

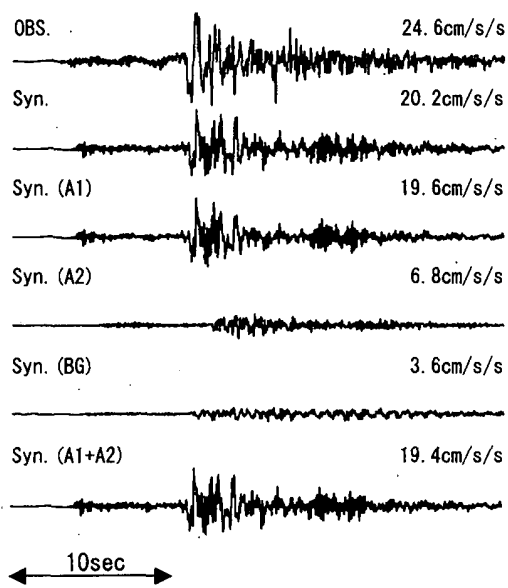

OKYH03

(a)加速度

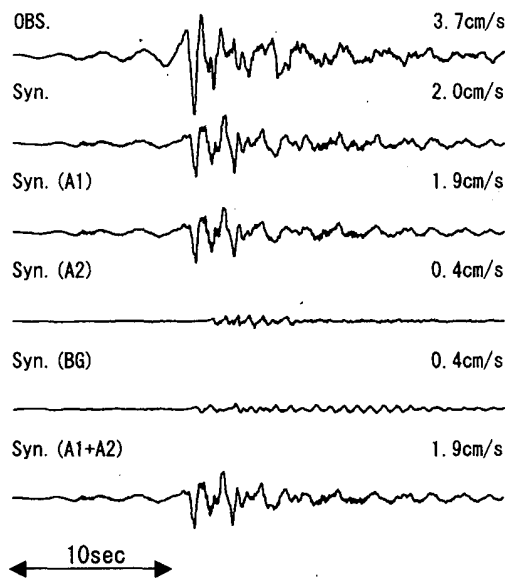

OKYH03

(b) 速 度

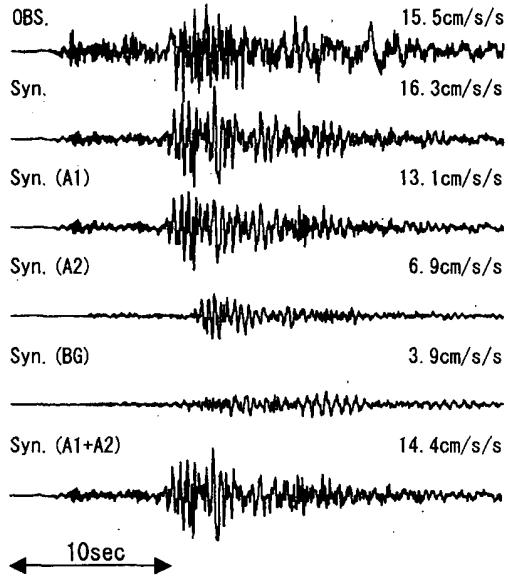

HRSH06

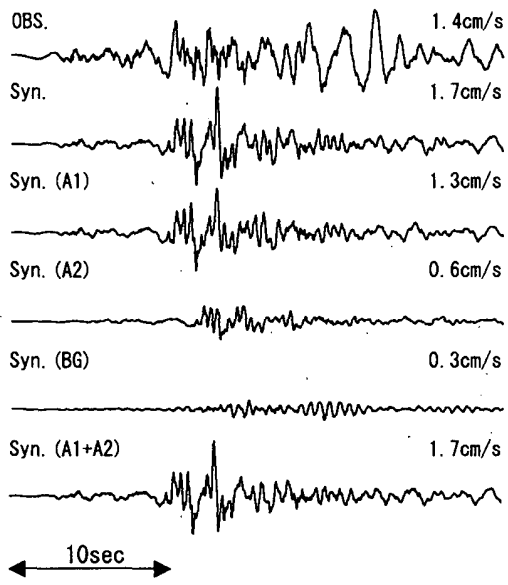

HRSH06

図 8 赤碕(TTRH04)，岡山(OKYH03)，口和(HRSH06)における地中の観測波形と合成波形との比較(EW 成分)

(各図とも上から，観測記録，合成結果，Asperitylのみ，Asperity2のみ，背景領域のみ，アスペリティのみの合成結果)

最大速度はこれに比べるとやや低く，長周期成分の評価精度がやや 低いことが考えられる．前述のように，震源近傍の観測点では，合 成波形におよぼす背景領域の寄与は小さく，震源の近くにアスペリ ティが見られることから，地震動はアスペリティのみから生成され る強震動によりほぼ説明できると考えられる。一方、図 8 に示すよ うに、震源から離れた TTRH04 では，背景領域でのモーメント解放 量が大きく、しかもアスペリティと背景領域までの距離がほぼ等し くなることから背景領域から生成される長周期地震動の寄与が大き. くなっている.

図 9 に-Net，図 10 Kik-Net の観測地点における観測波形に対 する合成波形(アスペリティのみを考慮した場合)の最大值の比(合成/ 観測)を示す、各図の標準偏差は, K-Net が 0.57 と 0.52(最大加速度と 最大速度), Kik-Net が 0.32 と 0.31 であり(一つだけ大きくはずれた TTRH02 を除く), Kik-Netに比べK-Net の方がばらつきが大きいこと がわかる。これは, 震源から半径 $50 \mathrm{~km}$ 程度の範囲では地表の最大加 速度が概ね $200 \mathrm{~cm} / \mathrm{s}^{2}$ を超えていることから ${ }^{54)}$ ，地中の観測点である Kik-Net に比べ，地表の観測点である K-Net の観測波形は地盤の非線 形性の影響を大きく受けたためと考えられる.

本検討では本震と余震の震源放射特性の違いは符号のみでしか考

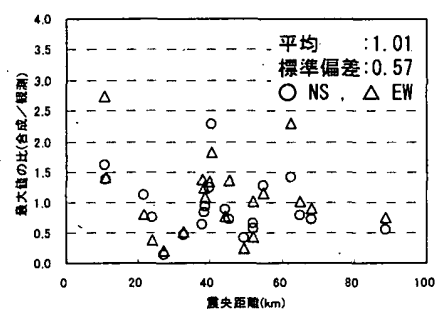

(a) 最大加速度

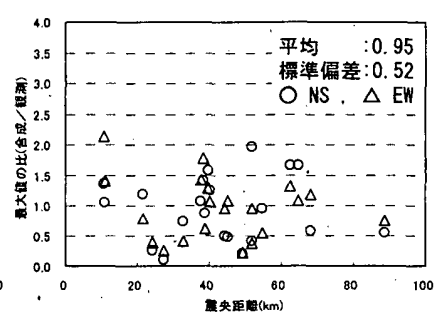

(b)最大速度
図 9 観測波形と合成波形(アスペリティのみ)との 最大值の比と震央距離との関係 $(\mathrm{K}-\mathrm{Net})$

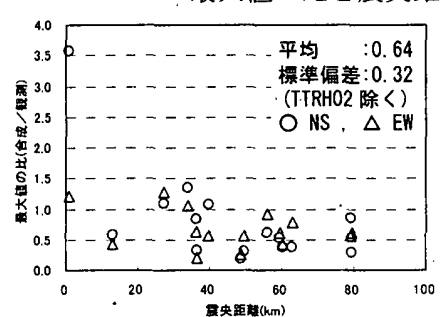

(a) 最大加速度

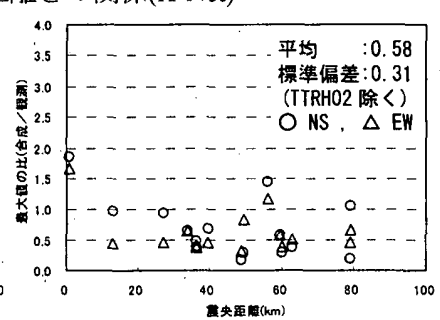

(b) 最大速度
図 10 観測波形と合成波形(アスペリティのみ)との 最大值の比と震央距離との関保(Kik-Net) 
慮していない，そのため，前述のようにSMNH01 で見られたような 成分によって観測波形と合成波形の一致度が異なる現象は震源放射 特性によるものと考えられる. 釜江ら ${ }^{8}$ は既往の震源放射特性に関す る観測的な研究に基づき，本来周波数に依存しない震源放射特性に ついて，その周波数依存性を考慮する方法を提案している，彼らは $0.5 \mathrm{~Hz}$ 以下では理論的放射特性を示し, $5 \mathrm{~Hz}$ 以上では等方的になると している.ここでは， $0.5 \mathrm{~Hz}$ 以下(2 秒以上)の長周期成分を対象に， 本震と余震のラディエーションパターン倸数を理論的に求め, その 比を補正係数とし，これを合成波形の最大值に乗じるという方法で 震源放射特性の補正を行った。

本震のラディエーションパターン係数は，一様なすべり角を想定 して分割小断層每に求められるが，図 I に示すように断層面のすべ り角は一様ではないため, ここではアスペリティでの平均值を使用 した.この補正は，地震動におよぼす地盤の非線形性の影響が小さ いと考えられる Kik-Net の地中観測地点に対して実施した.

図 11 に観測波形に対する合成波形の最大速度值の比と震央距離と の関係を震源放射特性の補正前・後について, Radial 方向と Transverse 方向についてそれぞれ示す，合成波形はアスペリティのみを考慮し た場合である.

震源放射特性の補正を行わない場合，特に震源ごく近傍の観測点 では最大值の比が大きくずれていることがわかる。これに対して， 震央距離が伸びるにつれて最大值の比は一定值に近づいていること がわかる．これは，適切な余震を選択したこと，震央距離が遠くな ることにより断層の広がりの影響が薄れ，点震源に近くなるためと 考えられる.これに対して, 震源放射特性の補正を行うことにより， 震源に近い観測点での最大值の比が改善されており, 補正の有効性 を示唆するものと考える
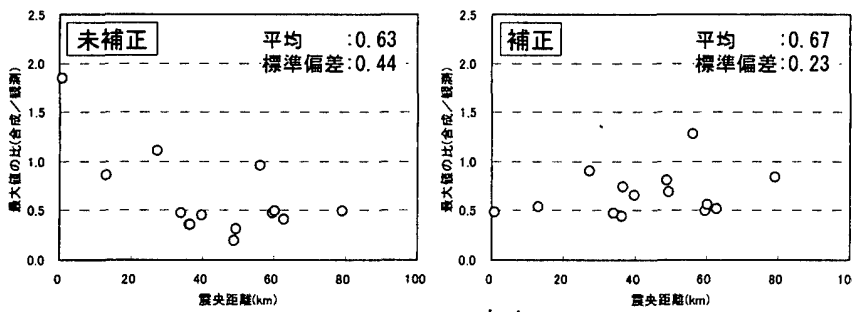

(a)Transverse 方向
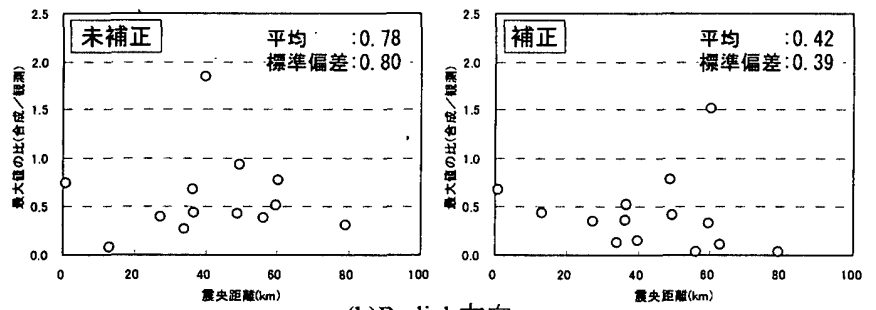

(b)Radial 方向

図 11 観測波形と合成波形(アスペリティのみ)との最大值の比と震央 距離との関係におよぼす震源放射特性の影響

(最大速度，周波数 $\leqq 0.5 \mathrm{~Hz}, \mathrm{Kik}-\mathrm{Net}$ )

\section{6. 結論}

2000 年 10 月 6 日鳥取県西部地震の最適震源モデルを経験的グリー ン関数法によるフォワードモデリングにより構築した．その結果， 二箇所（震源の南西側の浅い部分と梁い部分）のアスペリティと背 景領域からなるモデルを提案した.
(1) 震源ごく近傍の観測点の強震動は, 震源の南西側の浅い部分と 深い部分の二つのアスペリティのみから生成される強震動によ りほぼ説明できた，そのサイズ，地震モーメントおよび応力降 下量は深い部分が $4.8 \mathrm{~km} \times 6.0 \mathrm{~km}, 1.99 \times 10^{18} \mathrm{Nm}, 28 \mathrm{Mpa}$ ，浅い 方が $6.0 \mathrm{~km} \times 4.8 \mathrm{~km}, 0.99 \times 10^{18} \mathrm{Nm}, 14 \mathrm{Mpa}$ である.震源全体の アスペリティの総面積と地震モーメントとの関倸は, アスペリ ティの総面積がやや小さいものの, Somerville et al.の経験式によ ってほぼ説明できた，一方，震源から離れた地点では，アスペ リティ以外の背景領域から生成される長周期地震動の影響が大 きくなる。

（2）震源の破壊伝播様式は複雑であり，震源から破壊が同心円状に 伝播すると考えた場合には，破壊伝播の方向が異なるため震源 ごく近傍の SMNH01 での観測波形は再現できない.このことは， 鳥取県西部地震では，震源の破壊過程が重要であったことを示 唆するものと考えられる．また，将来の大地震を想定した強震 動予測では，震源の破壊過程も重要なパラメータであると考え られる.

（3）提案した最適震源モデルを用いて震源周辺(震央距離約 $70 \mathrm{~km}$ 以 内)の地震観測地点を対象に強震動シミュレーションを行った. その結果, 加速度合成波形の継続時間や包絡形状, 速度合成波 形の位相や形状はよく再現できた．最大值の一致度は, Kik-Net 観測地点に比べ K-Net 観測地点の方がばらつきは大きく，地盤 の非線形性の影響を強く受けたためと考えられる.

(4) 本震と経験的グリーン関数として用いた余震との震源放射特性 の違いを考慮することによって，震源に近い観測点での最大值 の一致度が改善され，震源放射特性の補正の有効性を示唆する ものと考えられる.

\section{謝辞}

本検討では, 防災科学技術研究所の K-Net および Kik-Net の観測波 形，Hi-Net の震源情報および Freesia のメカニズム解を使用させてい ただきました. (独)産業技術総合研究所の関口春子博士には震源イン バージョン結果を使用させていただくとともに破壊過程についてご 教授いただきました．京都大学大学院の平田美佐子氏には初期破壊 および主破壊開始点についてご教授いただきました。（財）地域地盤 環境研究所の宮腰 研博士には震源の特性化結果を使用させていた だきました，また，查読委員には非常に有益なご意見をいただきま した．最後に記して謝意を表します。

\section{参考文献}

1) 気象庁: 平成 12 年(2000 年) 10 月 6 日の鳥取県西部地震の余震活動につい て, 報道発表資料(平成 12 年 10 月 7 日 16 時 00 分), 2000.10 .

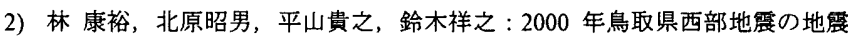
動強さの評価, 日本建築学会構造系論文集，第 548 号, pp.35-41，2001.10.

3）翠川三郎, 藤本一雄 : 2000 年鳥取県西部地震の震源域での地震動強さ, 日 本建築学会構造系論文集，第 549 号，pp.59-65，2001.11.

4）入會孝次郎，釜江克宏，Arben Pitarka：直下地震による強震動のハイブリ ッドシミュレーション法, 日本地震学会講演予稿集, 1994 年秋季大会, C26, 1994.10

5) Kamae, K., K. Irikura and A. Pitarka : A technique for simulating strong ground motion using hybrid Green's function, Bulletin of the Seismological Society of America, Vol.88, pp.357-367, 1998.4. 
6)例えば, 地震調查推進研究本部：地震関係基磷調查交付金による地下構造 調查報告について, http://www.jishin.go.jp/main/kozo/

7) Irikura,K. : Prediction of strong acceleration motions using empirical Green's function, Proceedings of the 7th Japan Earthquake Engineering Symposium, pp.151-156, 1986.12

8）釜江克宏，入合孝次郎，福知保長：地域的な震源スケーリング則を用いた 大地震(M7 級)のための設計用地震動予測, 日本建策学会構造系論文報告集, 第 416 号, ·pp.57-70, 1990.10.

9）例えば，防災科学技術研究所の强震観測網(K-Net)，基盤強震観測網 (Kik-Net), 高感度地震観測網(Hi-Net), http://www.bosai.go.jp/jindex.html

10) 入倉孝次郎, 香川敬生, 釜江克宏, 関口春子: 強震動予測のためのレシピ, 第 3 回都市直下地震災害総合シンポジウム，a-21，pp.125-128，1998.10.

11）入倉孝次郎，三宅弘恵，岩田知孝，釜江克宏 : 周期带域に応じた強震動評 価法の高精度化，地震災害軽減のための強震動予測マスターモデルに関す る研究，第 1 回シンポジウム論文集，pp.89-96，2002.3.

12) Somerville, P. G., K. Irikura, K., R. Graves, S. Sawada, D. Wald, N. Abrahamson, Y. Iwasaki, T. Kagawa, N. Smith and A. Kowada : Characterizing crustal earthquake slip models for the prediction of strong ground motion, Seismological Research Letters, Vol.70, No.1, pp.59-80, 1999.

13）壇一男, 渡辺基史, 佐藤俊明, 石井 透: 断層の非一様すべり破壊モデル から算定される短周期レベルと半経験的波形合成法による強震動予測のた めの震源断層のモデル化, 日本建築学会構造系論文集, 第 545 号, pp.51-62, 2001.7

14）釜江克宏, 入倉孝次郎：1995 年兵庫県南部地震の断層モデルと碾源近傍に おける強震動シミュレーション; 日本建築学会構造系論文集, 第 500 号, pp.29-36, 1997.10

15) 釜江克宏, 入倉孝次郎：1994 年ノースリッジ地震 $(M w=6.7)$ の震源モデル, 第 10 回日本地震工学シンポジウム, pp.643-648，1998.12.

16）釜江克厷，入倉孝次郎：トルコ、コジャエリ，台湾・集集地震の祳源の特 性化と強震動シミュレーション, 第 11 回日本地震工学シンポジウム(投稿 中)

17) Miyake, H., T. Iwata, and K. Irikura : Source characterization of inland crustal earthquakes for near-source ground motions, Proceedings of 6th International Conference on Seismic Zonation, II-32B, 2000:

18) Miyakoshi, K., T. Kagawa, H. Sekiguchi, T. Iwata and K. Irikura : Source characterization of island earthquakes in Japan using source inversion results : 12th World Conference on Earthquake Engineering, 1850, 2000.1.

19) 宮腰 研 : 私信

20）地震調查推進研究本部：地震に関する評価，強震動評価， http://www.jishin.go.jp/main'index.html

21) 防災科学技術研究所：K-Net，強震観測網，http://www.k-net.bosai.go.jp!

22）防災科学技術研究所：Kik-Net, 基盤強震観測網,

http://www.kik.bosai.go.jp/kik

23) 防災科学技術研究所: Hi-Net, 高感度地震観測網, http://www.hinetdata.bosai.go.jp/

24）関口春子, 岩田知孝: K-net, KiK-net 地震記録を用いた断層破塄過程の推定, http://sms.dpri.kyoto-u.ac.jp/iwata/tr.source.html

25) 岩田知孝; 関口春子: 2000 年鳥取県西部地震の震源断層の実体, SEISMO, pp.5-7, 2001.3.

26）堀川腈央：2000.年鳥取県西部地震の断層モデル, http://www.gsj:go.jp/ horikawa/2000Tottori/source.html

27) 井出 哲: 鳥取県西部地震の近地地震波に上る解析, http://www.eri.u-tokyo.ac.jp:ide/TTR/ttrI.html

28) Yagi, Y. and M. Kikuchi : Source Rupture Process of the Tottori-ken Seibu earthquake of Oct. 6, 2000, http://wwweic.eri.u-tokyo.ac.jp/yuji/tottori/

29) 福山英一,William L. Ellsworth, Felix Waldhauser, 久保篤規: 2000 年鳥取県西 部地震の詳細断層構造，地球惑星関連学会合同大会, S3-007, 2001.6.

30) 関口春子, 岩田知孝: 2000 年鳥取県西部地震の震源過程と地震発生の場,
地球惑星関連学会合同大会,S3-006,2001.6.

31）関口春子, 岩田知孝: 祳源過程が支配する震源近傍强震動 -2000 年鳥取県 西部地震一, 日本地震学会講演予稿集 2001 年度秋季大会,A73,2001.10.

32) 啮谷拓郎, 中尾節郎, 西田良平, 竹内文朗, 渡辺邦彦, 梅田康弘: 2000 年 鳥取県西部地震に先行して発生した 1989 年, 1990 年および 1997 年の群発 的地震活動，地球惑星関連学会合同大会,S3-003,2001.6.

33）梅田康弘, 平田美佐子, 吉井弘治, 大見士朗, 伊藤潔: 2000 年鳥取県西部 地震の初期破壊について，地球惑星関連学会合同大会,S3-P001,2001.6.

34) 平田美佐子, 梅田康弘, 川方裕則, 伊藤潔 : 2000 年鳥取県西部地震の初期

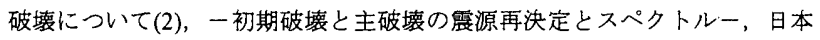
地霞学会講演子稿集, 2001 年度秋季大会, P129, 2001.10.

35) 梅田康弘：鳥取県西部地震の本震の初期破壊について, http://www2.rcep.dpri.kyoto-u.ac.jp/TOTTORl/syokihakai_j.html

36) 平田美佐子 : 私信

37) 防災科学技術研究所 : Freesia, 広帯域地震観測網, http://argent.geo.bosai.go.jp/freesia/index-j.html

38) Brune, J. N. : Tectonic stress and the spectra of seismic shear waves from earthquakes, Journal of Geophysical Research, Vol.75, pp.4997-5009, 1970.9.

39) Brune, J. N. : Correction, Journal of geophysical research, Vol.76, p.5002, 1971.7.

40) 川瀬 博, 松島信一, 佐藤智美, 伏見 実, 巽 誉樹: JMA87 型強震計の観 測記録に基づいた震源・伝播経路・サイトの各特性の分離，(その 1 ) 内陸 浅発地震の場合, 日本建築学会大会学術講演梗概集, 21101 , 構造 II, pp.201-202, 1999.9.

41) 気象庁監修, 月刊気象

42) 入倉孝次郎, 香川敬生, 関口春子: 経験的グリーン関数を用いた強震動予 測方法の改良, 日本地震学会講演予稿集, No.2, B25, 1997.9.

43) 関口春子：私信

44）宮武 隆: 震源物理に基づく震源モデル，一強震動予測のために一，月刊 地球，号外 No.37, pp.42-46, 2002.6 .

45) 菊地正幸, 山中佳子: 遠地実体波解析, 10 月 6 日鳥取県西部の地震(M7.3), EIC 地震学ノ一ト, No.93s, 2000.10.6, http://wwweic.eri.u-tokyo.ac.jp/EIC/EIC News/001006.html

46) Irikura, K. : Semi-empirical estimation of strong ground motions during large earthquakes, Bulletin of the Disaster Prevention Research Institute, Kyoto University, Vol.33, Part2, No.298, 1983.6.

47) Faccioli, E. : A study of strong motions from Italy and Yugoslavia in terms of gross source properties, Geophysical Monograph, 37, Maurice Ewing, AGU, Vol.6, pp.297-309; 1986

48) 佐藤智美 : Kik-net 強震記録を用いた鳥取県西部地震とその余震のラディエ ーションパターン及び fmax の検討, 日本地震学会講演予稿集 2001 年度秋 斈大会,A56,2001.10

49) 吉田 望, 中村 晋, 末䈏岩雄: 1995 年兵庫県南部地震における地盤の非線 形挙動とその予測，第 23 地盤祳動シンポジウム，pp.39-52, 1995.10.

50) 吉中龍之進, 桜井春輔, 菊地宏吉編著: 岩盤分類とその適用, 岩盤工学体 系[1], 土木工学社

51) 藤谷昌弘, 嶋田昌義, 小池 豊, 古田一郎：地盤の変形特性把握のための 室内試験と原位置試験の対比,「地盤および土構造物の動的問題における地 盤材料の変形特性一試験法・調查法および結果の適用一」に関する国内シ ンポジウム，発表論文集，社団法人土質工学会，pp.259-268, 1993.1.

52) 永野正行, 加藤研一, 武村雅之: 2000 年鳥取県西部地震時の震源断層近傍 に扔ける基盤地震動の推定; -1995 年兵庫県南部地震との比較-, 日本建築 学会構造系論文集, 第 550 号, pp.39-46, 2001.12.

53) 松元康広, 岩田知孝: 2000 年鳥取県西部地震( $\left.\mathrm{M}_{M N A} 7.3\right)$ の断層面上の高周波 $(2 \sim 10 \mathrm{~Hz})$ 地震波の生成過程の推定,

http://sms.dpri.kyoto-u.ac.jp/yasuhiro/tottori.html

54) 防災科学技術研究所 : K-Net,Kik-Netによる最大加速度分布, http://www.bosai.go.jp/ad!Jpn/news/tottori/tottori_k-net.html

(2002年 3 月 8 日原稿受理，2002年 8 月20日採用決定） 